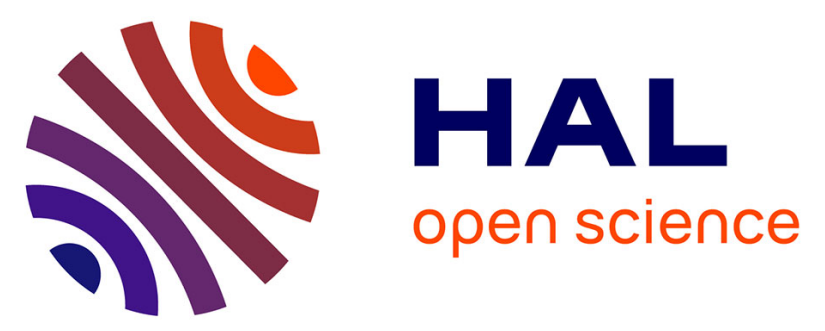

\title{
Clinical Aspects of STAT3 Gain-of-Function Germline Mutations: A Systematic Review
}

\author{
Alexandre Fabre, Sarah Marchal, Vincent Barlogis, Bernard Mari, Pascal \\ Barbry, Pierre-Simon Rohrlich, Lisa Forbes, Tiphanie Vogel, Lisa \\ Giovannini-Chami
}

\section{To cite this version:}

Alexandre Fabre, Sarah Marchal, Vincent Barlogis, Bernard Mari, Pascal Barbry, et al.. Clinical Aspects of STAT3 Gain-of-Function Germline Mutations: A Systematic Review. Journal of Allergy and Clinical Immunology: In Practice, 2019, 7 (6), pp.1958-1969.e9. 10.1016/j.jaip.2019.02.018 . hal-02413508

\section{HAL Id: hal-02413508 \\ https://hal.science/hal-02413508}

Submitted on 25 Oct 2021

HAL is a multi-disciplinary open access archive for the deposit and dissemination of scientific research documents, whether they are published or not. The documents may come from teaching and research institutions in France or abroad, or from public or private research centers.
L'archive ouverte pluridisciplinaire HAL, est destinée au dépôt et à la diffusion de documents scientifiques de niveau recherche, publiés ou non, émanant des établissements d'enseignement et de recherche français ou étrangers, des laboratoires publics ou privés.

\section{(ㄷ)(1) $\$$}

Distributed under a Creative Commons Attribution - NonCommerciall 4.0 International 


\section{Clinical aspects of STAT3 gain-of-function germline mutations: A Systematic Review}

Alexandre Fabre MD $\mathrm{PhD}^{1,2 \$}$, Sarah Marchal MBBS ${ }^{3 \$}$, Vincent Barlogis MD $\mathrm{PhD}^{4}$, Bernard Mari $\mathrm{PhD}^{5}$, Pascal Barbry $\mathrm{PhD}^{5}$, Pierre-Simon Rohrlich $\mathrm{MD} \mathrm{PhD}^{6,7}$ Lisa R Forbes $\mathrm{MD}^{8}$, Tiphanie P Vogel MD $\mathrm{PhD}^{8^{*}}$, Lisa Giovannini-Chami MD $\mathrm{PhD}^{3,7^{*}}$

${ }^{1}$ Pediatric multidisciplinary pediatric APHM, Timone Enfant, Marseille, France

${ }^{2}$ Aix Marseille Univ, INSERM, GMGF, Marseille, France

${ }^{3}$ Pediatric Pulmonology Department, Hôpitaux pédiatriques de Nice CHU-Lenval, Nice, France

${ }^{4}$ Pediatric Hematology Department, APHM, Timone Enfant, Marseille, France

${ }^{5}$ Université Côte d'Azur, CNRS, IPMC, 06560 Valbonne, France

${ }^{6}$ Pediatric Hematology Department, CHU de Nice, Nice, France

${ }^{7}$ Université de Nice-Sophia Antipolis, Nice, France

8 Department of Pediatrics, Immunology Allergy and Rheumatology, Baylor College of Medicine, Center for Human Immunobiology, Texas Children's Hospital, Houston, Texas, USA

\$, *These authors contributed equally to this work

*Corresponding author: Pr. Lisa Giovannini-Chami

Pediatric Pulmonology and Allergology Department, Hôpitaux pédiatriques de Nice CHU-

Lenval, 57 avenue de la Californie, 06200 NICE, France

E-mail: giovannini-chami.1@pediatrie-chulenval-nice.fr

Tel: +33492030531

Fax: +33 492030529

Funding source: none

Conflict of Interest: none for all authors

Word count abstract: 230

Word count: 3885 


\section{Abstract}

Background: STAT3 gain-of-function (GOF) germline mutations have been recently described. A comprehensive overview of this early-onset multiorgan autoimmune and lymphoproliferative disease has not yet been compiled.

Objective: We have conducted a systematic review of published STAT3 GOF cases in order to describe clinical, diagnostic and therapeutic aspects of the disease.

Methods: A systematic review including articles published before 10/10/2018 in Pubmed, WoS and CENTRAL databases was performed. We described cases of patients with STAT3 GOF germline mutations with genetic analysis and a concordant phenotype if functional analyses were not performed for the mutation.

Results: The search identified 18 publications describing 42 unique patients. Twenty-eight different mutations were described. Onset of disease was very early with an average age of 3 (0.5-5) years old. The most frequent manifestations were: autoimmune cytopenias (28/42), lymphoproliferation (27/42), enteropathy (24/42), interstitial lung disease (15/42), thyroiditis (13/42), diabetes (10/42), and post-natal growth failure (15/21). Immunodeficiency was not always a predominant feature. Most patients required significant immunosuppressive therapy. Five patients received hematopoietic stem cell transplantation, 4 died from complications. Improvement of symptoms was observed for 8 out of 9 patients that received targeted biotherapies. 
69 Conclusions: STAT3 GOF syndrome is a new clinical entity to consider when confronted 70 with a patient with early-onset poly-autoimmunity, lymphoproliferation, and growth failure. 71 At this time, precise therapeutic guidelines are lacking, but use of anti-IL-6 receptor and JAK 72 inhibitor biologics are attractive possibilities.

73 


\section{Highlights box.}

\section{What is already known about this topic?}

STAT3 gain-of-function (GOF) germline mutations have been recently described. A comprehensive overview of this early-onset multiorgan autoimmune and lymphoproliferative disease has not yet been compiled.

\section{What does this article add to our knowledge?}

We identified 42 unique patients. Typical disease was early-onset with very early endocrine autoimmunity, then pseudo-celiac enteropathy, followed by lymphoproliferation, autoimmune cytopenias and interstitial lung disease in the context of severe growth failure.

\section{How does this study impact current management guidelines ?}

STAT3 GOF syndrome is a new entity to consider when confronted with a patient with early onset poly-autoimmunity, lymphoproliferation and/or short stature. There is emerging evidence for the use of targeted biotherapies in this disorder.

Key words: autoimmunity; lymphoproliferative disease; GOF; Evans syndrome; interstitial lung disease; celiac disease; short stature; early onset diabetes; child 
Abbreviations:

99 STAT: $\operatorname{signal} \mathrm{t} r$ ansducer and act ivat or of $\mathrm{t} r$ anscript ion

100 GOF: ga in -of -funct ion

101 GnomAD: Genome Aggregation Dat abase

102 IL: in t er l eukin

103 JAK: Janus kina se

104 LGL: 1 arge granular 1 ymphocyt ic

105 SH2: Sr c homology 2

106 Ex AC: Exome Aggregation Consortium

107 SOCS: suppressor of cyt okine signal ing

108 EBV: Epst ein-Ba r r vir u s

109 ITP: immune thrombocytopenic pur pura

110 AIHA: a ut oimmune hemolyt ic a nemia

111 NK: natural killer

112 Ig: immu noglobul in

113 HLA: human leukocyt e ant igen

114 ILD: in ter st it ial $1 \mathrm{ung}$ disea se

115 IPF: idiopat hic pul monary fibrosis

116 DIP: desqua mat ive int er st it ial pneumonit is

117 LIP: 1 y mphocyt ic int er st it ia 1 pneumonit is

118 DLCO: diffusing capacit y of the 1 ungs for carbon monoxide

119 LRTI: 1 ower respirat or y tract infect ions

120 TPO: thyroper oxidase

121 MRI: magnet ic resonance imaging

122 GH: growt h hor mone

123 SD: st andard deviat ion 
124 IGF1: in sul in -l ike growt h fact or -1

125 GVH: graft versus host

126 ALPS: a ut oimmune 1 y mphoprol if er at ive syndrome

127 FAS: fir st a po pt osis signal

128 IPEX: immune dysregulat ion, pol yendocrinopathy, ent er opat hy, X-l inked

129 FOXP3: forkhead box P3

130 APDS: act ivat ed phosphoinosit ide 3-kina se del t a syndrome

131 CHAI : CTLA-4 hapl oinsufficiency wit h a ut oimmune infil $\mathrm{t}$ a t ion

132 LATAIE: LRBA deficiency wit h a ut oant ibodies, Treg defect s, a ut oimmune

133 infil tration and enteropathy

134 IBD: infla mmat or y bowel disea se

135 COOP: cryptogenic organizing pneumonia 
137

138

139

140

141

142

143

144

145

146

147

148

149

150

151

152

153

154

\section{Introduction}

The transcription factor signal transducer and activator of transcription 3 (STAT3), one of 7 members of the STAT family of transcription factors, is a critical regulator of multiple processes, including cellular proliferation, survival, differentiation, and regulation of autoimmunity and inflammation ${ }^{1}$. Therefore, STAT3 mutations (gain-of-function (GOF) or dominant negative) can result in immunodeficiency, autoimmunity or malignancy. STAT3 dominant negative germline mutations are well known, and lead to a primary immune deficiency syndrome (known as Buckley or Job Syndrome, or autosomal dominant hyper IgE syndrome OMIM: 147060$)^{2}$. STAT3 GOF somatic mutations have been reported in malignancies such as LGL leukemia and hepatocellular adenoma ${ }^{3}$. STAT3 GOF germline mutations were discovered recently and lead to early-onset multiorgan dysfunction (OMIM: 615952), including autoimmune disorders, lymphoproliferation, susceptibility to infection and severe growth failure ${ }^{1,3-5}$.

In 2014 and 2015, 3 major studies reported the first 19 patients with STAT3 GOF, describing genetics, clinical features and basic immunophenotyping ${ }^{1,4,6}$. Only case reports have been published thereafter without a comprehensive overview of clinical aspects and natural history of the disease. Recently a study on management with targeted biotherapies reported 4 additional patients ${ }^{7}$. The phenotype of STAT3 GOF is diverse, which makes its clinical definition and diagnosis difficult. The first manifestations of STAT3 GOF can be nonspecific inflammation and/or lymphoproliferation involving varied organ systems and, therefore, a STAT3 GOF patient could be first seen by a clinician of any subspecialty not yet familiar with this new immune dysregulation syndrome. Herein we have complied a systematic review of published STAT3 GOF cases in order to describe the genetics, functional studies and clinical aspects of the disease. 
162

163

164

165

166

167

168

169

170

171

172

173

174

175

176

177

178

179

180

181

182

183

184

185

\section{Methods}

\section{Patients}

This systematic review was conducted in accordance with the Preferred Reporting Items for Systematic Reviews and Meta-analyses (PRISMA) guidelines. A systematic search was conducted (10/10/2018) to identify studies reporting cases of patients with STAT3 GOF germline mutations. The literature search and evaluation were performed in 3 databases, MEDLINE (Pubmed), Web of Science (WoS) and CENTRAL (Cochrane Central Register of Controlled Trials), for articles published since 01/01/2014 (the first report of STAT3 GOF germline mutation is Flannagan et al., 2014). The following research keywords in English were used: (STAT3 AND "gain of function" or "signal transducer and activator of transcription 3" and "gain of function"), (STAT3 AND "Activating germline mutations" or "signal transducer and activator of transcription 3" and "Activating germline mutations") and (STAT3 AND "activating mutation" or "signal transducer and activator of transcription 3" and "activating mutation"). Another search was manually performed in Google scholar using the function cited by for Flannagan et al., 2014, Haapaniemi et al., 2015 and Milner et al., 2015. Abstracts and full-length text were screened for all suitable articles. We excluded duplicate articles or congress abstracts. To be eligible for inclusion, studies and case reports were required to describe cases of patients with STAT3 GOF germline mutations with genetic analysis and a concordant phenotype if functional analyses were not performed for the mutation. All types of publications, such as articles, reviews, editorials, letters, and correspondence, reported in English or in French, published online between January 1, 2014 and October 10, 2018 were included.

\section{Genetic evaluation}


186 Frequency of variants was determined using the gnomAD database

\section{Statistical analysis}

Data were collected and organized using Microsoft Excel (Microsoft, Redmond, WA, USA) and statistical analysis was performed using R. Data were presented as median and (first, third) quartiles.

\section{Results}

The search identified 18 publications describing 42 unique patients. The list of included articles is presented in Table E1, sorted by date of publication. Figure 1 summarizes the PRISMA diagram.

At this time, 28 different mutations from 42 cases have been described, located mostly in the DNA binding domain (Figure 2 and Table E2). All patients were heterozygous for the mutation, 21 were de novo mutations and 7 were inherited in an autosomal dominant manner within 5 different families. Six unaffected members were described within 4 out of these 5 families. Penetrance is thus incomplete. Analysis of described STAT3 variants in the gnomAD database showed only one mutation as already reported (p.R246Q with a frequency of 1/246408 alleles), all the others are not reported. All mutations reported but one (an in frame amino acid deletion) are missense. All variants were predicted pathogenic or probably pathogenic by UMD-predictor and disease causing by Mutation Taster. According to ExAC data, STAT3 is a constrained gene with a pLI (a indicator of intolerance to loss of function) of 
2111 (the least tolerant), ${ }^{8}$ and indeed all the mutations reported are very rare. These features 212 support autosomal dominant inheritance?

213 Functional studies were reported for all mutations except $4^{10,11}$, and confirmed gain of

214 function of STAT3 (Table E2). The functional tests developed were (i) an in vitro STAT3 215 reporter luciferase assay under basal or stimulated conditions (IL-6/growth hormone) in A4, 216 HEK293 or INS-1E cells, and (ii) SOCS3 expression levels under basal or stimulated (IL-21) 217 conditions in EBV-transformed patient cell-lines or primary cells. Of note, under basal 218 conditions, luciferase reporter assay was normal for two patients (but abnormal in stimulated 219 conditions) and under stimulated conditions the assay was normal for two other patients (but 220 abnormal in basal conditions). GOF mutations resulted in at least ten-fold increase of 221 luciferase reporter assays for seven patients. The absence of obvious genotype-phenotype 222 correlations and the fact that STAT3 hyperactivity does not appear to correlate with the 223 severity of the phenotype suggest that environmental and other genetics factors may 224 contribute to this syndrome. ${ }^{12}$

\section{Clinical aspects}

227 Clinical expression phenotypes of STAT3 GOF syndrome are very diverse. Among the 42 cases $(\operatorname{sex} \text { ratio }(\mathrm{M} / \mathrm{F})=18 / 22=0.82)^{1,4,6,7,13-18,10,19-22,11,23-25}$, the most frequent features were 229 hematologic disease, failure to thrive/short stature and multi-organ autoimmune disorders.

230 Onset of disease was very early with an average age of onset of $3(0.5-5)$ years old (Figure 3), 231 including 17 cases occurring before one year. Eight patients died, at a median age of 12.5 232 years (5.5-18.25), including 4 from complications of stem cell transplantation. The following description is based on the 42 reported cases. 
237 Hematologic disease was the most frequent finding (35/42), especially autoimmune 238 cytopenias (28/42), including immune thrombocytopenia (ITP) $)^{4,6,11,15-17,19,22,23}$ (24/28), 239 autoimmune hemolytic anemia (AIHA) $)^{1,4,11,15-17,19,22,23}(19 / 28)$ and neutropenia ${ }^{4,16,17}(9 / 28)$ 240 (Table E3). AIHA and ITP were observed concurrently in 15 cases $^{4,7,11,15-17,19,22,23}$. There was 241 an autoimmune pancytopenia in 4 cases $^{4}$. Age of onset was specified in 8 cases; median age 242 of onset was 3.5 years old (Figure 3). Immunodeficiency (hypogammaglobulinemia or lymphopenia or recurrent infections)

244 was not as severe as could be expected from the phenotype of STAT3 dominant negative 245 mutations, but it was described in many cases (28/42). Infection susceptibility was described 246 in most STAT3 GOF patients (23/28), mainly recurrent upper and lower respiratory tract 247 infections $(11 / 23)^{1,4,6,14,16,19,21,24}$ leading to bronchiectasis in 2 cases. 248 Hypogammaglobulinemia was reported in about half of patients ${ }^{1,4,6,11,14,15,17,21,22,24}$ (18/28); it 249 was associated with clinical infection in 16 cases. A decrease of immune cells to varying 250 degrees was noticed for T-cells ${ }^{4,6,11,19,20}$ (8/28), NK-cells $s^{1,6,11,16,19,24}$ (9/28), and B-cells, 251 particularly memory B-cells ${ }^{4,19,20}$ (4/28). Further, T regulatory cell levels were reported in 11 252 patients, and were decreased in 10/11 cases, all with multi-organ autoimmunity. Th17 cells 253 levels were also reported in 4 cases, but were high in only one case. Lymphoproliferation (27/42) was described mainly with adenopathy $1,4,7,11,15-17,19,20$ 255 (23/27) and hepatosplenomegaly ${ }^{1,4,7,14-17,19,20,23}$ (23/27), which was concomitant in 19 cases. 256 There was mediastinal adenopathy in 3 cases. Age of onset of lymphoproliferation was 257 specified in 8 cases, the median age was 2.5 (1.9-3.5) years old for adenopathy and 3 (1.9-8) 258 years old for hepatosplenomegaly (Figure 3). Hemophagocytic lymphohistiocytosis was 259 described in 1 case $^{7}$. Malignancy was described in 2 cases. One adult patient had Hodgkin 260 lymphoma $^{4}$ and 1 patient developed LGL leukemia ${ }^{1}$ at the age of 14. IgA level was reported 
261 in 16 cases, being elevated in 5 cases $^{10,14,20,21}$ and low in 8 cases ${ }^{1,11,15,17,22}$. Hyper $\operatorname{IgA}$ was

262 invariantly associated with enteropathy.

\section{Gastrointestinal manifestations}

265 Hepatic and digestive diseases were described in 26 cases (Table E4). Enteropathy was found 266 in 24/42 patients (Table E5). Average age of onset, reported for 11 patients, was 1 (0.5-1.02) 267 year, and most (9/11) before the second year (Figure 3). The clinical signs were diarrhea (17 268 patients), abdominal pain (4) and vomiting (2), associated with growth failure in 12 cases.

269 The disease was initially classified as celiac disease in 9 cases. Response to gluten free diet 270 was reported for 7 patients: 1 patient responded $^{1}, 1$ patient responded partially ${ }^{1}, 1$ patient 271 responded in combination with azathioprine and tacrolimus ${ }^{10}$, and there was no response for 4 272 patients $^{1,14,20,24}$. For the 5 patients with reported HLA, 3 were DQ2 or DQ8 positive. Both 273 DQ2 positive patients were responsive to a gluten free diet. Of the 11/42 patients for which 274 celiac antibodies (anti-gliadin (G), anti-tissue transglutaminase (TTG) or anti-endomysium 275 (E)) were tested ${ }^{1,6,10,18,20}, 9$ were positive and 2 were negative ${ }^{1}$. The 2 patients with negative 276 celiac antibodies had no clinical signs of enteropathy. Among the 9 patients with positive 277 celiac antibodies, 7 had positive anti-G (5 isolated anti-G , 1 anti-G/E, 1 anti-G/TTG) and 1 278 had isolated anti-TTG. Antibody specificity was not reported for the last patient.

Gastrointestinal biopsy results were reported in multiple STAT3 GOF patients. 281 Pathology of the esophagus showed normal ${ }^{18}$ or mild changes, such as basal cell 282 hyperplasia $^{4,21}$. Pathology of the stomach showed moderate gastritis in 9 patients ${ }^{1,4,14,18,20,21,24}$, 283 with lymphocytic infiltration noted in 4 . In 14 patients ${ }^{1,4,6,10,14,18,20-22,24}$, abnormalities of the 284 duodenum were reported. This was predominantly villous atrophy (11 patients $\left.{ }^{1,4,10,14,18,20}\right)$ as 285 well as inflammation (12 patients ${ }^{1,4,6,10,14,18,20,21,24}$ ) with intraepithelial lymphocyte infiltration 
286

287

288

289

in 9 patients ${ }^{1,6,10,14,18,20,21,24}$. For 5 patients with sequential biopsies, 2 had a normalization of the biopsy ${ }^{1,18}, 1$ patient's was initially normal followed by a second abnormal one ${ }^{1}$, and 2 no improvement ${ }^{20,24}$. Colonic biopsies were normal in only 1 case $^{14}$ and showed colitis in 5 cases $^{4,6,11,18}$.

Additionally, 9 patients were reported with liver disease $e^{4,7,10,11,20,22}, 4$ with autoimmune hepatitis (with anti-DNA and anti-smooth muscle antibodies) requiring liver transplant in 2 of them. One patient had achalasia ${ }^{4}$. Three patients developed pancreatic exocrine insufficiency ${ }^{1,20}, 2$ of them also had diabetes ${ }^{1}$.

Seven patients affected by enteropathy were treated with targeted biotherapies (tocilizumab and ruxolitinib or tofacitinib) that improved their symptoms, need for TPN or NG tube feeds and nutrition status. One patient that benefited from stem cell transplantation had improvement in his gastrointestinal symptoms, especially diarrhea ${ }^{4}$. One patient gained control of her diarrhea with immunosuppressive treatment (azathioprine and tacrolimus) in association with a gluten free $\operatorname{diet}^{10}$.

\section{Pulmonary manifestations}

Twenty-two patients developed lung disease with a predominance of interstitial lung disease and recurrent lower respiratory tract infection (Table E6). 15/42 patients developed interstitial lung disease $e^{1,4,7,10,11,15,20,21,24}$. The median age of onset, specified in 7 cases, was 16 (9-18) years old and was substantially delayed in regards to hematologic, endocrine and gastrointestinal features (Figure 3). Among these 15 patients, 7 had lymphocytic interstitial pneumonitis (LIP) ${ }^{4,7,15,20,21}, 2$ granulomatous lung disease ${ }^{11,21}, 2$ desquamative interstitial pneumonitis (DIP) ${ }^{1,24}, 1$ idiopathic pulmonary fibrosis (IPF) ${ }^{4}$ and 1 cryptogenic organizing pneumonia $(\mathrm{COOP})^{1}$. With regard to the clinical presentation, asthma-like symptoms in early infancy were described in 3 patients who presented later with ILD. A lung biopsy was 
311 performed in 3 cases $^{1,4,15}$. The first case showed diffuse interstitial fibrosis (IPF) ${ }^{4}$. The second

312 displayed a diffuse interstitial fibrosis that was associated with alveolar thickening and 313 macrophages (DIP) ${ }^{1}$. The third case displayed atypical interstitial lymphoblastic infiltrate $314(\mathrm{LIP})^{15}$

Three patients required long-term oxygen therapy and 1 invasive ventilation.

316 Immunosuppressive treatment of pulmonary manifestations was detailed in 8 cases (steroids 317 in 6 cases, tacrolimus in 2 cases, mycophenolate mofetil in 2 cases, azathioprine in 1 case, 318 sirolimus in 1 case, cyclosporine in 1 case, and tocilizumab combined with ruxolitinib in 2 319 cases, tocilizumab combined with tofacitinib in one case). Immune suppression had a positive 320 effect in 2 cases: 1 patient who benefited from tocilizumab associated with ruxolitinib 321 required less oxygen ${ }^{20}$; 1 patient who was treated with mycophenolate mofetil had 322 improvement in $\mathrm{DLCO}^{4}$. One pulmonary patient had a bone marrow transplant, but died from 323 multiple organ failure ${ }^{21}$.

11/42 patients had recurrent lower respiratory tract infections ${ }^{1,4,6,14,16,19,21,22,24}$ (LRTI).

325 There was 1 case of Mycobacterium avium lung infection ${ }^{6}$. Among patients with LRTIs, 6 had 326 hypogammaglobulinemia, 4 T-cell lymphopenia, 4 decreased NK-cells and 1 pan327 lymphopenia. Seven of these patients were treated with immunosuppressive treatment and the 328 chronology of lung infection with regard to treatment onset was not detailed.

\section{Endocrinopathies}

331 Endocrine diseases were also a frequent feature, reported in 21/42 patients (Table E7). Type I 332 diabetes was the earliest endocrine manifestation in STAT3 GOF syndrome $(10 / 42)^{1,4,11,16-18}$. 333 It appeared before 1 month of life in 3 cases and between 1 month and 12 months in 3 cases.

334 The median age of onset of type I diabetes was 8 weeks (2.3-35.5) (Figure 3). HLA 335 genotyping was high risk in 3 cases $^{1,16}$ and low risk in 2 cases. 
Hypothyroidism was found in $13 / 42^{1,4,7,10,11,16-18,21}$ STAT3 GOF patients. It appeared

before 1 month of life in 2 cases. The median age of onset of thyroid disease was $2(0-2.5)$ years old. Hypothyroidism and diabetes were co-morbid in 4 cases $^{1,11,16,18}$.

To a lesser extent, the pituitary gland was affected. One patient was described with

340 isolated central corticotropin deficiency ${ }^{20}$. There was 1 case of presumed pituitary dysfunction

341 that responded well to GH treatment ${ }^{4}$. Finally, 1 patient was reported with GH insensitivity ${ }^{16}$.

Growth failure

344 Weight and/or height at birth were recorded in 14 cases, intrauterine growth restriction (weight and/or height at birth $<-2 \mathrm{SD}$ ) was present in 5 cases $(35 \%)^{1,16,20,21}$ (Figure 4). Postnatal growth failure (height and/or weight $<-2 \mathrm{SD}$ ) was presented in 15 cases among 21 where it was reported $(75 \%)^{1,4,7,10,16,18,20,21,24}$. Height was less than or equal to -4SD in 5 cases ${ }^{1,4,16,20}$. Growth failure was associated with intrauterine growth restriction in 3 cases. IGF1 was low in 7 of 10 patients tested, however, 5 also had enteropathy which could have affected nutritional status and so the IGF1 level. GH stimulation was performed in $4 \mathrm{cases}^{1,4,16}$, there was a

351 positive response in 3 cases $^{1,4,16}$. 7 patients benefited from GH treatment, it was effective in $3523^{4,21}$ and showed a partial response in $4^{1,20,21,24}$.

\section{Other features}

355 Dysmorphic features are not a predominant feature of STAT3 GOF syndrome (2/37). 356 Cutaneous disease (16/42) was mainly atopic dermatitis $(12 / 16)^{1,4,6,7,10,11,20,21}$ and alopecia $357(4 / 16)^{4,10,14}$ (Table E8). The age of onset of cutaneous disease was reported in 4 cases all 358 under the age of 2 years. 
361 treatment with tocilizumab ${ }^{4}$. The age of onset was specified in 4 cases, with a median of 11

$362(9-13.25)$ years of age.

Six patients suffered from osteoporosis ${ }^{1,4,14,20,24}$ and 2 from osteopenia ${ }^{4}$; among them 2

364 had received corticosteroid treatment. There was 1 case of acroosteolysis ${ }^{4}$, resorption of the

365 distal bony phalanges. Delayed bone age was noted in 6 cases $^{4,16,24}$. Two patients presented

366 with joint laxity ${ }^{4}$. Dental abnormalities such as decay or delayed teeth eruption (a common

367 feature of STAT3 dominant negative mutations) were noted in 5 cases $^{1,4,16,20}$.

368 Renal disease was reported in 3 cases $^{14,20,22}$. One patient presented with

369 nephrolithiasis at an adult age. There was 1 case of proximal tubulopathy with severe

370 hypercalciuria at 5 years old, associated with cortical renal hyperechogenicities compatible

371 with microcysts, but without renal impairment. Finally, one patient had a chronic renal

372 impairment, and died from end stage renal failure.

373 Ocular affects were reported in $5 / 42^{\text {patients }}{ }^{1,19,20,22}$, including 2 patients with uveitis

374 and keratoconjunctivitis sicca in 2 cases. Neurological disease was not predominant, with 1

375 case of ocular myasthenia gravis ${ }^{4}, 1$ case of cerebral atrophy that led to abnormal

376 psychomotor development ${ }^{4}$, and 1 patient with cerebral palsy ${ }^{4}$. Three patients ${ }^{1,4}$ developed

377 thrombosis ( 1 internal carotid and 2 vena cava), but additional details were not provided.

378 Finally 1 patient developed disseminated intra-vascular coagulation ${ }^{7}$.

\section{Clinical Progression}

381 STAT3 GOF syndrome encompasses many target organ diseases with a sequential median

382 age of onset (Figure 3 and Figure 5). Endocrine and gastrointestinal disease is very early383 onset and appears clearly before the onset of hematologic disease. Poly-autoimmunity with $\geq$

3842 autoimmune diseases was frequent (29/42); $\geq 3$ autoimmune diseases was reported in 16/42

385 patients. Single organ autoimmune disease was reported in 10 patients and 3 patients had no 

enteropathy and oxygen support.

obvious autoimmunity. Although hematologic disease was also predominant, it was not invariant as 7 patients did not have any hematologic disease (Figure 6). Finally, 4 patients had neither poly-autoimmunity nor hematologic disease.

Most of the symptomatic patients with STAT3 GOF syndrome required significant immunosuppressive therapy. Treatment was outlined in 23 cases and is presented in Table 1.

Non targeted immunosuppressive therapies were overall ineffective.

Five patients ${ }^{4,7,16,21}$ received hematopoietic stem cell transplantation, 4 died from complications (GVH disease and systemic adenovirus in 1 case, multiple organ failure in 1 case, systemic adenovirus infection in 1 case and adenovirus pneumonia and post-transplant hemophagocytic lymphohistiocytosis in 1 case); the other had improved growth and a complete remission of his autoimmune disease $\mathrm{e}^{4}$.

Other therapeutic options consisted of targeting molecules which play an important role in the STAT3 pathway. Nine patients ${ }^{4,7,14,20,24}$ received anti-IL6 receptor monoclonal antibody therapy (tocilizumab), with a positive effect on autoimmune disease except in 1 patient $^{7}$. The effect nevertheless seems to plateau. In 1 case it was used in monotherapy ${ }^{4}$ and it resulted in improvement of the general condition, alleviation of diarrhea and increased Treg cells $^{14}$. In the 8 other patients tocilizumab was given with a Jak inhibitor (ruxolitinib or tofacitinib) and this showed clear improvement in 5 patients, most notably for their

\section{Discussion}

409 In recent years, multiple monogenic causes of early-onset autoimmunity and 410 lymphoproliferation have been identified, now including STAT3 GOF syndrome ${ }^{3,4,7,26-32}$. 
411 These disorders have overlapping clinical and immunologic features (Table 2). In addition to 412 these early-onset, monogenic autoimmune syndromes, the differential diagnoses for the 413 symptoms of STAT3 GOF syndrome are plentiful due to multiple features within each organ 414 system. Therefore, several differential diagnoses can be considered. Our systematic review 415 summarizes current knowledge about specific characteristics of the disease. Average onset of 416 organ systems appears to occur sequentially (Figure 3), with early-onset diabetes and 417 enteropathy preceding hematologic manifestations and lung disease.

418 The enteropathy was frequently initially diagnosed as pseudo-celiac, with villous 419 atrophy, but without the usual serologic signature. Only half of the patients tested had the 420 high risk HLA (compared to more than $95 \%$ in classic celiac disease). Gluten free diet had no 421 effect in most patients. STAT3 GOF patients presenting with early-onset IBD like phenotypes 422 lacked the classical histologic findings of IBD and lymphocyte infiltration. Early-onset endocrinopathies including neonatal diabetes and early onset thyroiditis

424 were among the first symptoms occurring during infancy. Polyautoimmunity (encountered in $42529 / 42$ patients) included arthritis, autoimmune hepatitis, alopecia areata and autoimmune 426 cytopenias notably later in life. Intra-uterine growth retardation was encountered in $1 / 3$ of 427 patients and post-growth failure in 3/4, with 5 patients $<-4$ SD. Growth failure is a 428 predominant feature of STAT3 GOF syndrome. This could be the consequence of digestive 429 disease (malabsorption), diabetes, hypothyroidism, respiratory insufficiency, frequent 430 infections or corticosteroid treatment. However, it could also be inherent to the STAT3 GOF 431 mutations. Indeed, STAT5b, is the major transcription factor downstream of $\mathrm{GH}$ 432 signaling ${ }^{31,33}$, and STAT3 activation can inhibit STAT5 phosphorylation ${ }^{16}$.

433 STAT3 GOF appears as a new etiology of ILD, mainly LIP as well as other forms of 434 ILD such as COOP or DIP. Pathology showed fibrosis in 2 patients. LIP r esul t s from 435 pulmonary interstitial accumulation of lymphocytes. Several 
436 publications have suggested that STAT3 plays a role in regulating

437 fibroblast function in fibrotic $1 \mathrm{ung}$ diseases and that aber $\mathrm{r}$ ant STAT3

438 signal ing plays a critical role in usual interstitial pneumonia and idiopathic pulmonary

439 fibrosis pathogenesis ${ }^{34}$.

440 Hematologic disease was frequent, onset after infancy and included lymphoproliferation,

441 immunodeficiency with infection susceptibility (mainly recurrent LRTI and rare opportunistic

442 infections), and autoimmune cytopenias. Despite the well-known association of somatic

443 STAT3 GOF mutations with malignancy, cancer was only reported in 2 patients. Given the 444 young average age of STAT3 GOF patients, long term followup will be critical to fully 445 understand the risk of malignancy in STAT3 GOF syndrome.

446 The immunologic consequences of STAT3 GOF mutations would be predicted to result 447 in expansion of Th17 cells and inhibition of Treg cells, which plays a critical role in the 448 development of autoimmunity ${ }^{5,10}$. This is because, among other triggers, STAT3 is activated 449 by IL-6 and plays an important role in differentiation of CD4 T-cells ${ }^{5}$. We hypothesize that, 450 due to the severity of disease in most symptomatic STAT3 GOF patients, the reported T cell 451 subsets were not performed in treatment naïve patients and that therapy with 452 immunosuppression impacted Th17 development.

453 STAT3 interacts with other STATs mainly via suppressor of cytokine signalling 3 454 (SOCS3), which is a downstream target of STAT3 and negative regulator of STAT3 455 signaling ${ }^{3-5}$. Through this mechanism, STAT3 is believed to inhibit STAT1 and STAT5 456 phosphorylation. Disruption of STAT5 activation leads to inhibition of Treg development. In 457 fact, most STAT3 GOF patients with reported T-cell subsets did have decreased Treg cells 458 counts, but, to date, the majority of the few patients examined have been found to have 459 normal levels of Th17 cells. 
Non-targeted immunosuppressive treatments were disappointing in this cohort.

461 Available biotherapies and bone marrow transplant constitute a real hope for these patients.

462 Use of targeted therapy with tocilizumab and ruxolitinib or other JAK inhibitors may change

463 the natural course of the disease. Bone marrow transplant could be a curative option when

464 life-threatening complications occur, but available data are insufficient to determine safety or 465 optimal conditions for this therapeutic option ${ }^{7}$.

466 This systematic review has some limitations. Four patients did not have any functional 467 tests and many papers did not include specific details of clinical aspects, most notably the 468 timing of onset of the different clinical features. A study reporting the complete natural 469 history of the disease with timing of the onset of the different manifestations would be worth 470 investigating. Nevertheless, the clinical summaries of STAT3 GOF made in this systematic 471 review will be a useful tool to select among patients with early onset autoimmunity and 472 lymphoproliferation to direct specific testing for STAT3.

STAT3 GOF syndrome is heterogeneous and patients do not universally present with 474 hematologic autoimmunity, or obvious lymphoproliferation, immunodeficiency or short 475 stature. They can also have a wide variety of solid organ manifestations such as pseudo-celiac 476 disease, pseudo-juvenile arthritis, endocrinopathies, interstitial lung disease, and cutaneous disease. However, notably, very early-onset diabetes or atypical celiac disease are clues to this syndrome and can be for a long time the only manifestation. with functional analysis of new mutations. This process is available only in expert centers, 481 using mainly luciferase reporter assays. SOCS3 level of expression has also been used as a 482 functional assay. Levels of GOF determined by luciferase reporter assay seem to be the best assessment in order to potentially delineate genotype-phenotype correlations in the future. 


\section{Conclusion}

486 STAT3 GOF syndrome caused by heterozygous, germline STAT3 GOF mutations is a new 487 clinical entity to think about when confronted with early-onset poly-autoimmunity with 488 lymphoproliferation, enteropathy, interstitial lung disease, and associated with severe growth 489 failure. Heterogeneity of the phenotype makes a precise clinical definition difficult. Currently, 490 genetic analysis is the only valid diagnostic method. At this time, defined therapeutic 491 guidelines are still lacking but use of anti-IL-6 receptor and JAK inhibitor biologics are 492 attractive possibilities while other future options, such as anti-STAT3 therapeutics, are being 493 developed.

494 


\section{References}

1. Flanagan SE, Haapaniemi E, Russell MA, Caswell R, Allen HL, De Franco E, et al. Activating germline mutations in STAT3 cause early-onset multi-organ autoimmune disease. Nat Genet. 2014;46:812-4.

2. Holland SM, DeLeo FR, Elloumi HZ, Hsu AP, Uzel G, Brodsky N, et al. STAT3 Mutations in the Hyper-IgE Syndrome. New England Journal of Medicine. 2007;357:1608-19.

3. Vogel TP, Milner JD, Cooper MA. The Ying and Yang of STAT3 in Human Disease. J Clin Immunol. 2015;35:615-23.

4. Milner JD, Vogel TP, Forbes L, Ma CA, Stray-Pedersen A, Niemela JE, et al. Earlyonset lymphoproliferation and autoimmunity caused by germline STAT3 gain-offunction mutations. Blood. 2015;125:591-9.

5. Hillmer EJ, Zhang H, Li HS, Watowich SS. STAT3 signaling in immunity. Cytokine Growth Factor Rev. 2016;31:1-15.

6. Haapaniemi EM, Kaustio M, Rajala HLM, van Adrichem AJ, Kainulainen L, Glumoff $\mathrm{V}$, et al. Autoimmunity, hypogammaglobulinemia, lymphoproliferation, and mycobacterial disease in patients with activating mutations in STAT3. Blood. 2015;125:639-48.

7. Forbes LR, Vogel TP, Cooper MA, Castro-Wagner J, Schussler E, Weinacht KG, et al. Jakinibs for the treatment of immune dysregulation in patients with gain-of-function signal transducer and activator of transcription 1 (STAT1) or STAT3 mutations. J Allergy Clin Immunol. 2018;

8. Lek M, Karczewski KJ, Minikel EV, Samocha KE, Banks E, Fennell T, et al. Analysis of protein-coding genetic variation in 60,706 humans. Nature. 2016;536:285-91.

9. Bennett CA, Petrovski S, Oliver KL, Berkovic SF. ExACtly zero or once: A clinically helpful guide to assessing genetic variants in mild epilepsies. Neurol Genet. 2017;3:e163.

10. Wienke J, Janssen W, Scholman R, Spits H, van Gijn M, Boes M, et al. A novel human STAT3 mutation presents with autoimmunity involving Th17 hyperactivation. Oncotarget. 2015;6:20037-42.

11. Maffucci P, Filion CA, Boisson B, Itan Y, Shang L, Casanova J-L, et al. Genetic Diagnosis Using Whole Exome Sequencing in Common Variable Immunodeficiency. Front Immunol. 2016;7:220.

12. Haddad E. STAT3: too much may be worse than not enough! Blood. 2015;125:583-4.

13. Lau C-Y, Mihalek AD, Wang J, Dodd LE, Perkins K, Price S, et al. Pulmonary Manifestations of the Autoimmune Lymphoproliferative Syndrome. A Retrospective Study of a Unique Patient Cohort. Ann Am Thorac Soc. 2016;13:1279-88. 
14. Khoury T, Molho-Pessach V, Ramot Y, Ayman AR, Elpeleg O, Berkman N, et al. Tocilizumab Promotes Regulatory T-cell Alleviation in STAT3 Gain-offunction-associated Multi-organ Autoimmune Syndrome. Clinical Therapeutics. 2017;39:444-9.

15. Weinreich MA, Vogel TP, Rao VK, Milner JD. Up, Down, and All Around: Diagnosis and Treatment of Novel STAT3 Variant. Front Pediatr. 2017;5:49.

16. Sediva H, Dusatkova P, Kanderova V, Obermannova B, Kayserova J, Sramkova L, et al. Short Stature in a Boy with Multiple Early-Onset Autoimmune Conditions due to a STAT3 Activating Mutation: Could Intracellular Growth Hormone Signalling Be Compromised? Horm Res Paediatr. 2017;88:160-6.

17. Nabhani S, Schipp C, Miskin H, Levin C, Postovsky S, Dujovny T, et al. STAT3 gainof-function mutations associated with autoimmune lymphoproliferative syndrome like disease deregulate lymphocyte apoptosis and can be targeted by $\mathrm{BH} 3$ mimetic compounds. Clin Immunol Orlando Fla. 2017;181:32-42.

18. Velayos T, Martínez R, Alonso M, Garcia-Etxebarria K, Aguayo A, Camarero C, et al. An Activating Mutation in STAT3 Results in Neonatal Diabetes Through Reduced Insulin Synthesis. Diabetes. 2017;66:1022-9.

19. Besnard C, Levy E, Aladjidi N, Stolzenberg M-C, Magerus-Chatinet A, Alibeu O, et al. Pediatric-onset Evans syndrome: Heterogeneous presentation and high frequency of monogenic disorders including LRBA and CTLA4 mutations. Clin Immunol. 2018; 188:52-7.

20. Fabre A, Marchal S, Forbes LR, Vogel TP, Barlogis V, Triolo V, et al. STAT3 GOF: A New Kid on the Block in Interstitial Lung Diseases. Am J Respir Crit Care Med. 2018;197:e22-3.

21. Gutiérrez M, Scaglia P, Keselman A, Martucci L, Karabatas L, Domené S, et al. Partial growth hormone insensitivity and dysregulatory immune disease associated with de novo germline activating STAT3 mutations. Mol Cell Endocrinol. 2018;473:166-77.

22. Russell MA, Pigors M, Houssen ME, Manson A, Kelsell D, Longhurst H, et al. A novel de novo activating mutation in STAT3 identified in a patient with common variable immunodeficiency (CVID). Clin Immunol Orlando Fla. 2018;187:132-6.

23. Takagi M, Hoshino A, Yoshida K, Ueno H, Imai K, Piao J, et al. Genetic heterogeneity of uncharacterized childhood autoimmune diseases with lymphoproliferation. Pediatr Blood Cancer. 2018;65.

24. Giovannini-Chami L, Vogel TP, Forbes LR, Fabre A, Trojani M-C, Leroy S, et al. STAT3 gain of function : a new aetiology of severe rheumatic disease. Rheumatology. 2018;

25. Camarero C, Leon F, Colino E, Redondo C, Alonso M, Gonzalez C, et al. Collagenous colitis in children: clinicopathologic, microbiologic, and immunologic features. J Pediatr Gastroenterol Nutr. 2003;37:508-13. 
26. Schubert D, Bode C, Kenefeck R, Hou TZ, Wing JB, Kennedy A, et al. Autosomal dominant immune dysregulation syndrome in humans with CTLA4 mutations. Nat Med. 2014;20:1410-6.

27. Gámez-Díaz L, August D, Stepensky P, Revel-Vilk S, Seidel MG, Noriko M, et al. The extended phenotype of LPS-responsive beige-like anchor protein (LRBA) deficiency. Journal of Allergy and Clinical Immunology. 2016;137:223-30.

28. Coulter TI, Chandra A, Bacon CM, Babar J, Curtis J, Screaton N, et al. Clinical spectrum and features of activated phosphoinositide 3-kinase $\delta$ syndrome: A large patient cohort study. J Allergy Clin Immunol. 2017;139:597-606.e4.

29. Neven B, Magerus-Chatinet A, Florkin B, Gobert D, Lambotte O, De Somer L, et al. A survey of 90 patients with autoimmune lymphoproliferative syndrome related to TNFRSF6 mutation. Blood. 2011;118:4798-807.

30. Barzaghi F, Amaya Hernandez LC, Neven B, Ricci S, Kucuk ZY, Bleesing JJ, et al. Long-term follow-up of IPEX syndrome patients after different therapeutic strategies: An international multicenter retrospective study. J Allergy Clin Immunol. 2018;141:1036-1049.e5.

31. Hwa V. STAT5B Deficiency: Impacts on Human Growth and Immunity. Growth Horm IGF Res Off J Growth Horm Res Soc Int IGF Res Soc. 2016;28:16-20.

32. Toubiana J, Okada S, Hiller J, Oleastro M, Lagos Gomez M, Aldave Becerra JC, et al. Heterozygous STAT1 gain-of-function mutations underlie an unexpectedly broad clinical phenotype. Blood. 2016;127:3154-64.

33. Kofoed EM, Hwa V, Little B, Woods KA, Buckway CK, Tsubaki J, et al. Growth hormone insensitivity associated with a STAT5b mutation. $\mathrm{N}$ Engl $\mathrm{J}$ Med. 2003;349:1139-47.

34. Pechkovsky DV, Prêle CM, Wong J, Hogaboam CM, McAnulty RJ, Laurent GJ, et al. STAT3-mediated signaling dysregulates lung fibroblast-myofibroblast activation and differentiation in UIP/IPF. Am J Pathol. 2012;180:1398-412. 
603

604

605

606

607

608

609

610

611

612

613

614

615

616

617

618

619

620

621

622

623

624

625

626

627

628

629

\section{Figure legends}

Figure 1. PRISMA flow diagram.

Fig. 2 Schematic of the STAT3 protein showing the location of mutations reported to cause STAT3 GOF.

STAT3 is divided into 6 domains: the N-terminal domain, coiled-coil domain, DNA binding domain, linker domain, Src-homology 2 ( $\mathrm{SH} 2)$ domain and transactivation domain (TA). Mutations shown represent mainly missense mutations and the resulting amino acid changes, but there is also one deletion. Mutations replicated in several patients are indicated in red by the number of patients reported and using bold lines.

\section{Figure 3. Age at onset.}

Age at onset of the disease and at onset of different clinical manifestations.

\section{Figure 4. Weight and height $\mathrm{z}$-scores at birth and last visit.}

Weight and height z-scores at birth and last visit.

\section{Figure 5. Kaplan-Meier survival curves.}

Kaplan-Meier survival curves of (A) overall survival, (B) diabetes mellitus, (C) enteropathy, (D) lymphadenopathy, (E) hepatosplenomegaly, (F) autoimmune cytopenias, (G) arthritis, and (H) interstitial lung disease (ILD). On the $\mathrm{X}$ axes, time is expressed in years. $\mathrm{Y}$ axes represent either the percentage of survival (in A) or the number of patients free of the disease (B-H). Solid lines represent survival curves and dotted lines the confidence intervals. 
630 Figure 6. Venn diagram of clinical manifestations.

631 Venn diagram of endocrine, gut, hematologic, articular and pulmonary clinical 632 manifestations.

633

634

635

636

637 
Figure 1. PRISMA Flow diagram

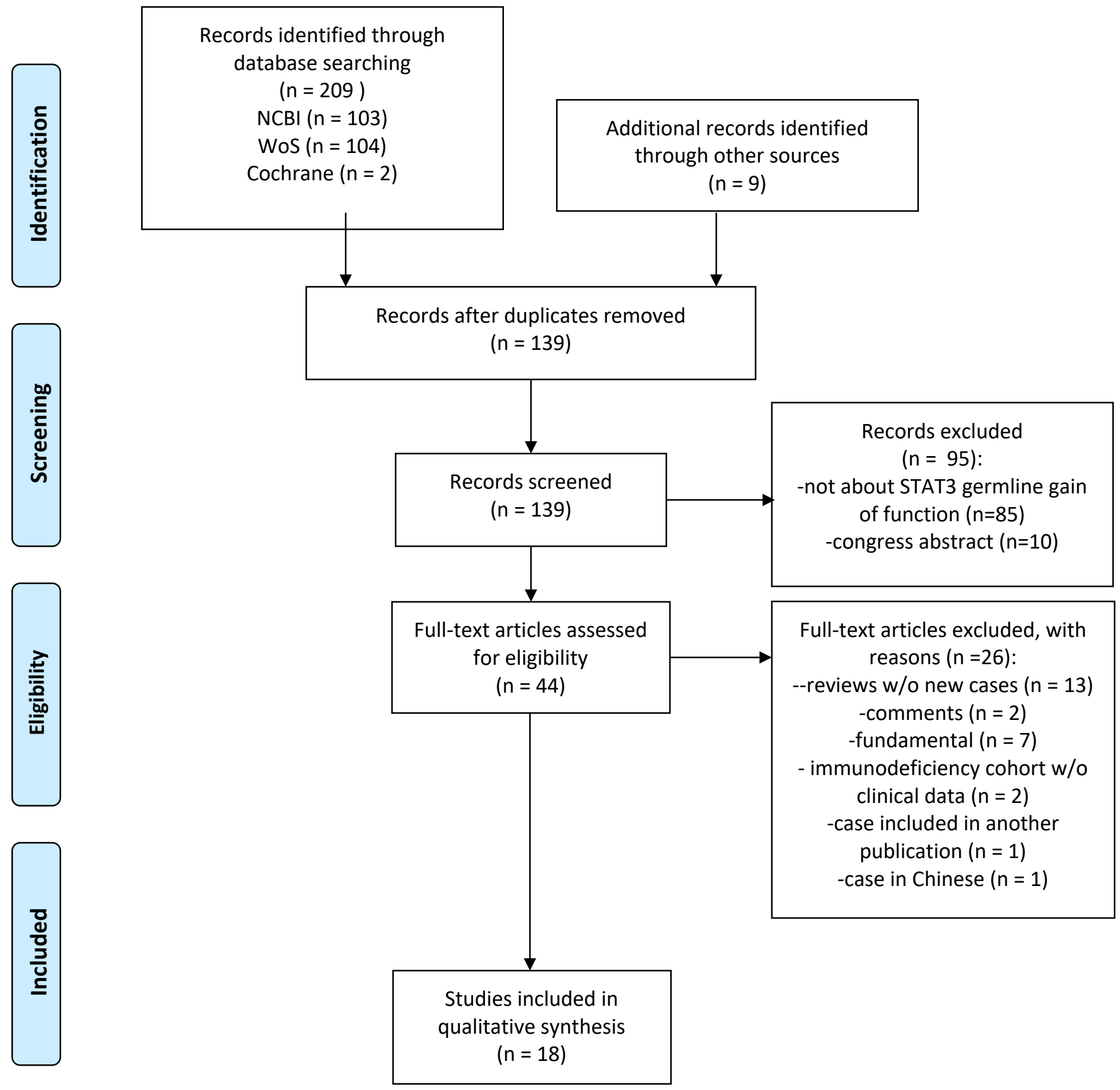

From: Moher D, Liberati A, Tetzlaff J, Altman DG, The PRISMA Group (2009). Preferred Reporting Items for Systematic Reviews and MetaAnalyses: The PRISMA Statement. PLoS Med 6(7): e1000097. doi:10.1371/journal.pmed1000097 


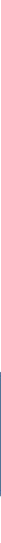


Age (years)

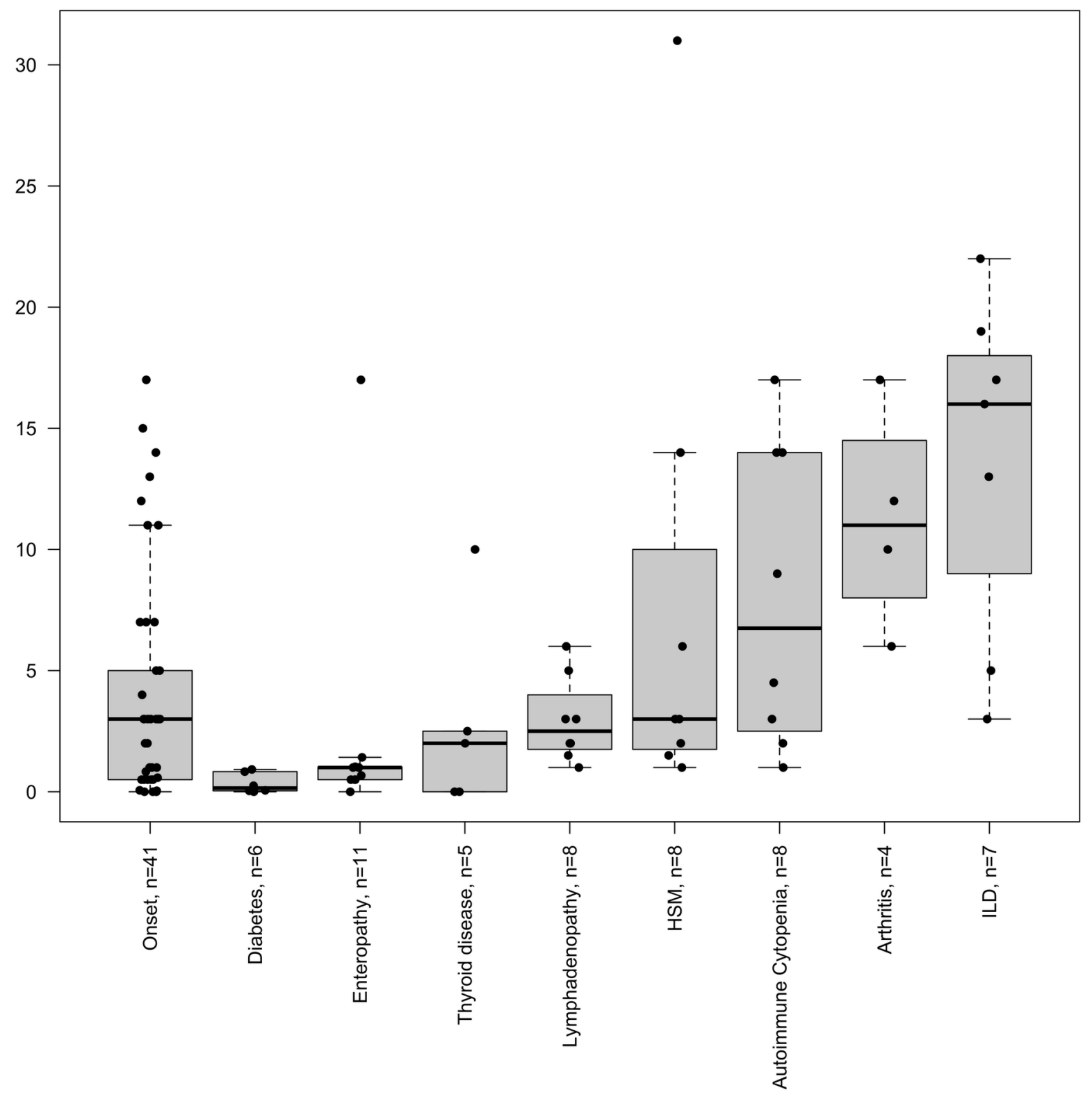


Z-score

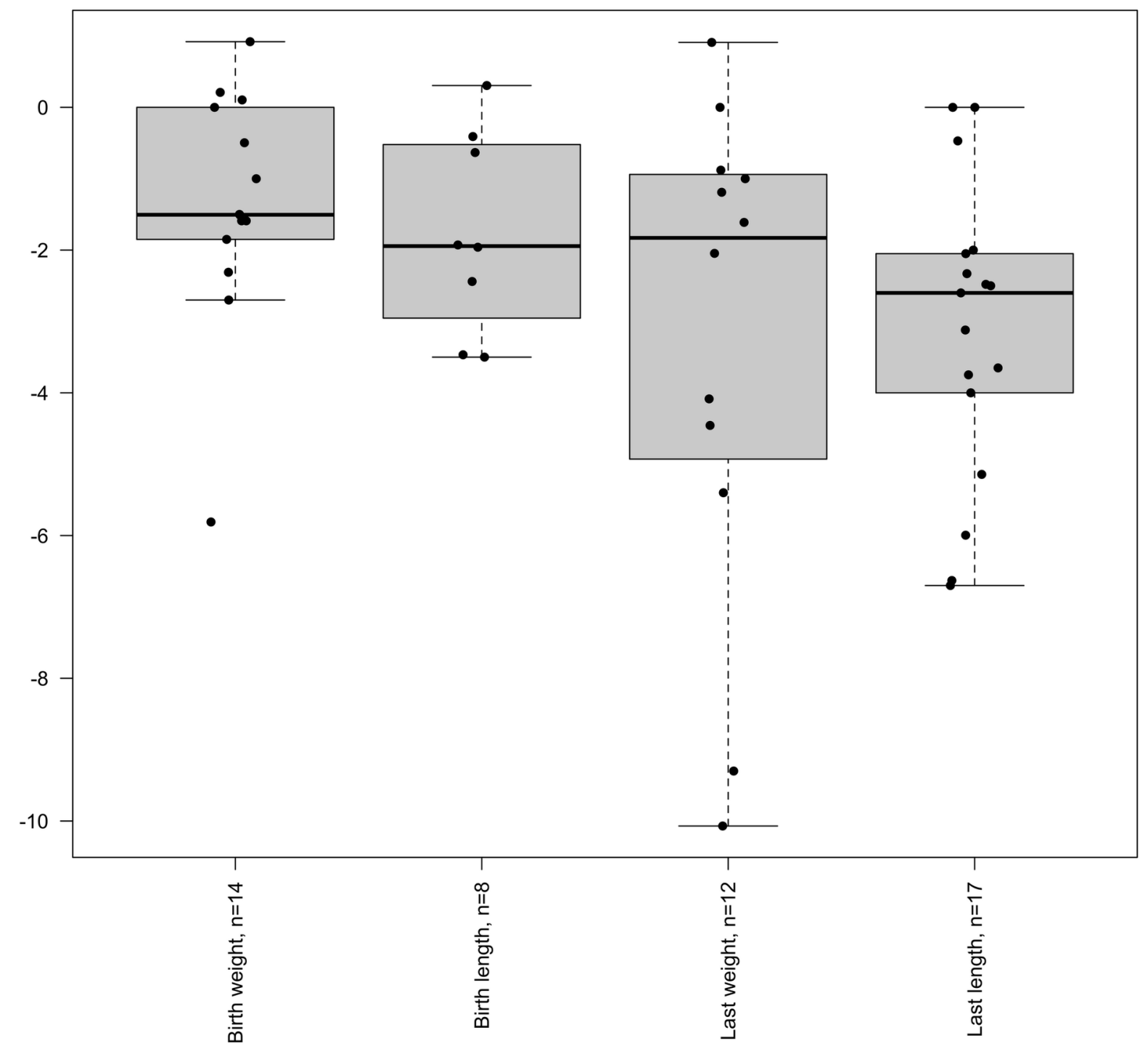


A Survival

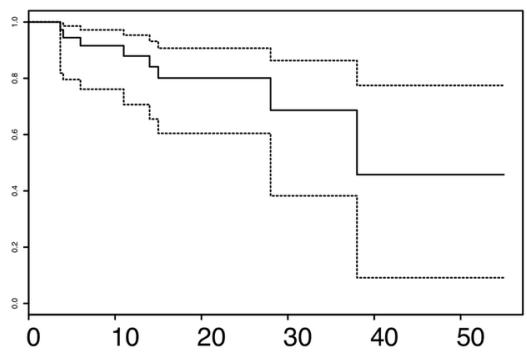

Enteropathy

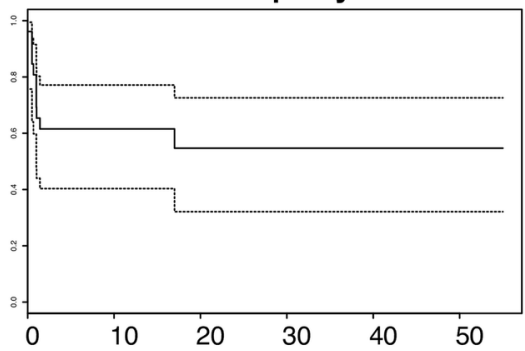

HSM

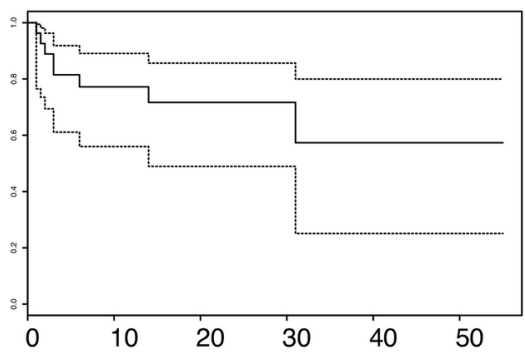

Arthritis

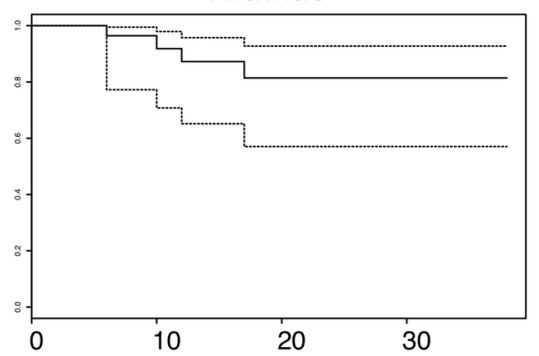

B

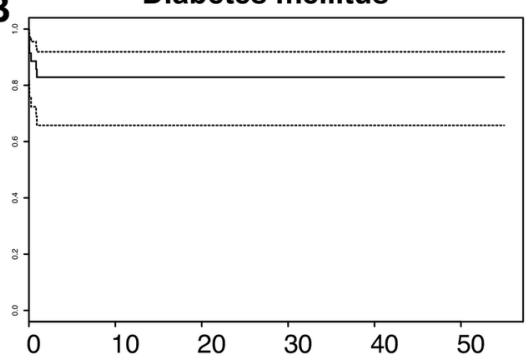

Adenopathies
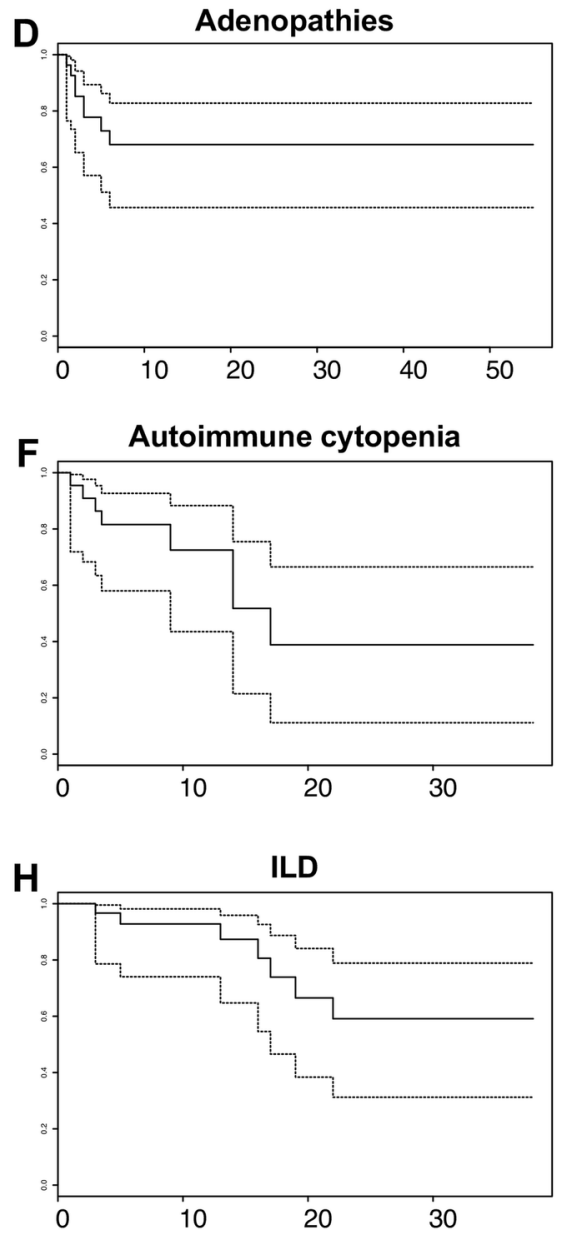
Gut

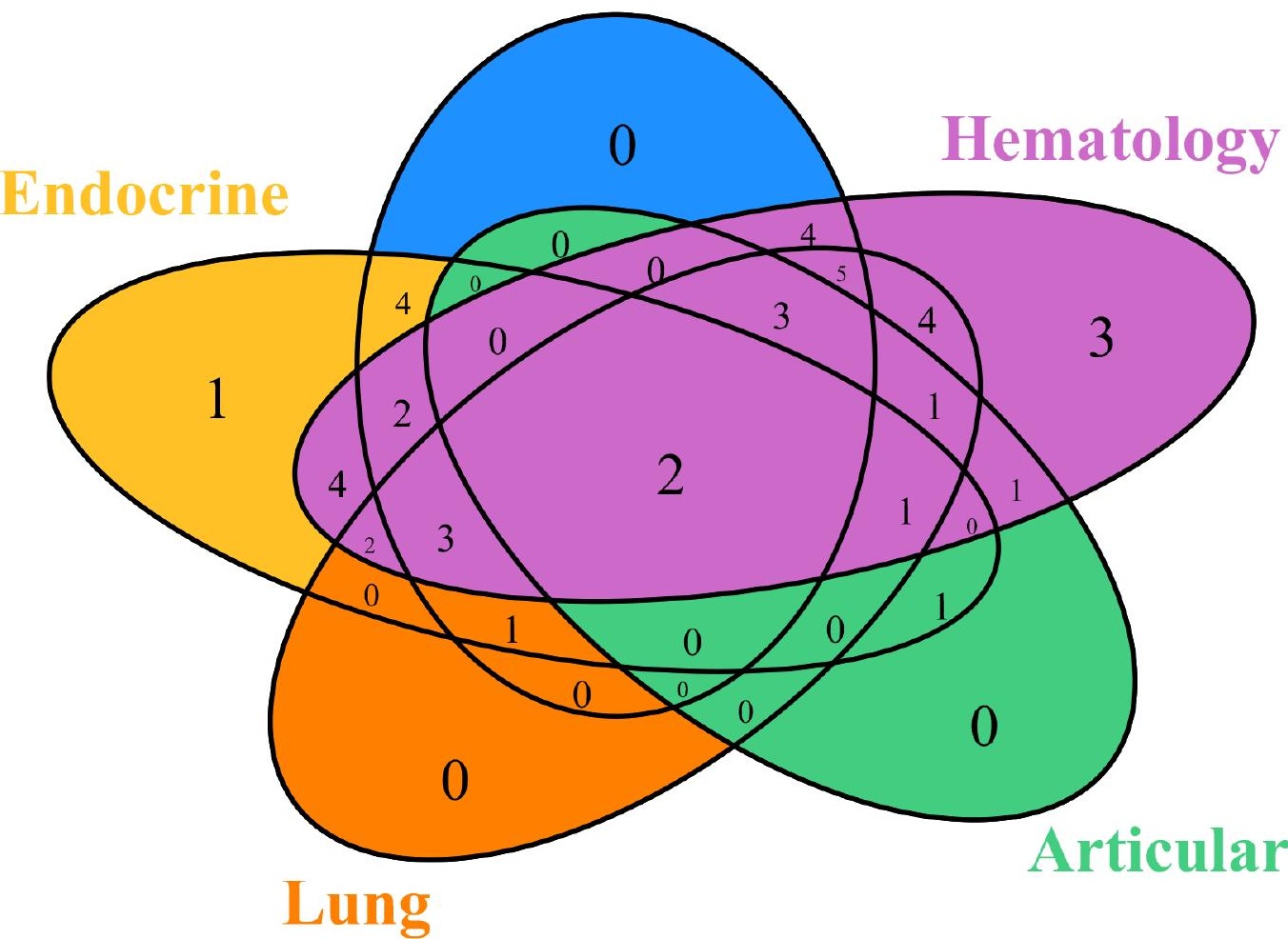


Table 1. Treatments reported in STAT3 GOF patients

\begin{tabular}{|c|c|c|c|c|}
\hline Treatments & Total & $\begin{array}{l}\text { Positive } \\
\text { effect }\end{array}$ & $\begin{array}{l}\text { Negative } \\
\text { effect / } \\
\text { no effect }\end{array}$ & $\begin{array}{l}\text { Not } \\
\text { determined }\end{array}$ \\
\hline \multicolumn{5}{|l|}{ Non targeted therapies } \\
\hline Systemic steroids & $17^{1,6,7,10,14,16,17,21,22,24}$ & $3^{14,16,17}$ & $6^{1,16,22,24}$ & $8^{6,7,10,21}$ \\
\hline Inhaled steroids & $2^{1,21}$ & - & $2^{1,21}$ & - \\
\hline Mycophenolate mofetil & $5^{1,4,7,17,22}$ & $2^{4,17}$ & $1^{7}$ & $2^{1,22}$ \\
\hline Tacrolimus & $4^{1,7,10}$ & $1^{1}$ & $2^{7,10}$ & $1^{1}$ \\
\hline Azathioprine & $4^{7,19,24}$ & - & $4^{7,19,24}$ & - \\
\hline Rituximab & $3^{7,15,19}$ & $1^{15}$ & $1^{7}$ & $1^{19}$ \\
\hline Sirolimus & $3^{7,21}$ & - & $3^{7,21}$ & - \\
\hline $\begin{array}{l}\text { Anti TNF-alpha } \\
\text { Infliximab } \\
\text { Adalimumab }\end{array}$ & $\begin{array}{l}3^{7,24} \\
1^{24} \\
1^{24}\end{array}$ & $\begin{array}{l}- \\
- \\
-\end{array}$ & $\begin{array}{l}3^{7,24} \\
1^{24} \\
1^{24}\end{array}$ & $\begin{array}{l}- \\
-\end{array}$ \\
\hline Methotrexate & $2^{7,24}$ & - & $2^{7,24}$ & - \\
\hline Cyclophosphamide & $2^{7}$ & - & $2^{7}$ & - \\
\hline Cyclosporine & $1^{21}$ & - & $1^{21}$ & - \\
\hline Abatacept & $1^{21}$ & - & $1^{21}$ & - \\
\hline Alemtuzumab & $1^{7}$ & - & $1^{7}$ & - \\
\hline Anti-IL1 & $1^{7}$ & - & $1^{7}$ & - \\
\hline HSCT & $5^{4,7,16,21}$ & $1^{4}$ & $4^{7,16,21}$ & - \\
\hline \multicolumn{5}{|l|}{ Targeted therapies } \\
\hline $\begin{array}{l}\text { Tocilizumab } \\
\text { Addition of jakinib }\end{array}$ & $\begin{array}{l}9^{4,7,14,20,24} \\
8^{4,7,20,24}\end{array}$ & $\begin{array}{l}8^{4,7,14,20,24} \\
5^{7,20,24}\end{array}$ & $\begin{array}{l}1^{7} \\
3^{4,7}\end{array}$ & $\begin{array}{l}- \\
-\end{array}$ \\
\hline
\end{tabular}


Table 2. Clinical features of single-gene defects with immune dysregulation ${ }^{3,4,7,26-32}$

\begin{tabular}{|c|c|c|c|c|c|c|c|c|c|}
\hline & STAT3 GOF & $\begin{array}{l}\text { STAT3 DN } \\
\text { (AD-HIES) }\end{array}$ & STAT1 GOF & STAT5b deficiency & APDS & ALPS & IPEX & LATAIE & CHAI \\
\hline Gene & STAT3 & STAT3 & STAT1 & STAT5b & PIK3CD & TNFRSF6 & FOXP3 & LRBA & CTLA-4 \\
\hline Transmission & $\mathrm{AD}$ & $\mathrm{AD}$ & $\mathrm{AD}$ & $\mathrm{AR}$ & $\mathrm{AD}$ & $\begin{array}{c}70 \% \mathrm{AD} \\
\text { (some somatic mutations) }\end{array}$ & $\mathrm{X}$-linked & AR & $\mathrm{AD}$ \\
\hline Onset of Symptoms & Childhood & Early infancy & Childhood & Childhood & $1-3$ years & $1-3$ years & Early infancy & Childhood & Childhood \\
\hline Lymphoproliferation & SM, HM & - & SM, HM & - & $\begin{array}{c}\text { LAD, SM, } \\
\text { ENT lymphoid } \\
\text { hyperplasia }\end{array}$ & $\begin{array}{c}80 \% \text { chronic } \\
\text { lymphoproliferation (>6 } \\
\text { months): } \\
\text { LAD, SM, HM }\end{array}$ & - & LAD, SM, HM & LAD, SM \\
\hline $\begin{array}{l}\text { Autoimmune disorder } \\
\text { (immune dysregulation) }\end{array}$ & $\begin{array}{c}\text { AIHA, ITP } \\
\text { Early-onset pseudo-celiac } \\
\text { enteropathy, } \\
\text { Interstitial lung disease, } \\
\text { Early-onset diabetes and } \\
\text { thyroiditis, } \\
\text { Arthritis, } \\
\text { Alopecia }\end{array}$ & - & $\begin{array}{c}\text { Thyroiditis, } \\
\text { Alopecia, Psoriasis, } \\
\text { Scleroderma, Lupus, } \\
\text { Pseudo-celiac } \\
\text { enteropathy, Colitis, } \\
\text { Autoimmune } \\
\text { hepatitis, } \\
\text { Autoimmune } \\
\text { cytopenia }\end{array}$ & $\begin{array}{c}\text { Interstitial lung disease, } \\
\text { ITP, } \\
\text { Thyroiditis, } \\
\text { Arthritis }\end{array}$ & $\begin{array}{c}\text { 30\% Cytopenias, } \\
\text { Insulin-dependent } \\
\text { diabetes, } \\
\text { Arthritis }\end{array}$ & $\begin{array}{c}\text { 70\% Cytopenias: } \\
\text { AIHA, ITP or neutropenia, } \\
\text { Rare other autoimmune } \\
\text { manifestations: nephritis, } \\
\text { hepatitis, biliary cirrhosis, } \\
\text { colitis, arthritis, vasculitis }\end{array}$ & $\begin{array}{c}\text { Early-onset } \\
\text { enteritis with } \\
\text { villous atrophy \& } \\
\text { lymphocytic } \\
\text { infiltrates, } \\
\text { Endocrinopathy: } \\
\text { diabetes } \\
\text { (sometimes } \\
\text { neonatal) \& } \\
\text { thyroiditis, } \\
\text { Hemolytic } \\
\text { anemia }\end{array}$ & $\begin{array}{c}\text { Enteropathy, } \\
\text { AIHA, ITP, } \\
\text { Interstitial lung disease, } \\
\text { Diabetes, } \\
\text { Hepatitis, } \\
\text { Psoriasis }\end{array}$ & $\begin{array}{c}>50 \% \text { Enteropathy } \\
>50 \% \text { Interstitial lung } \\
\text { disease, } \\
\text { AIHA, ITP }\end{array}$ \\
\hline Other & $\begin{array}{l}\text { Herpesvirus infections, } \\
\text { Fungal infections, } \\
\text { Bacterial infections, }\end{array}$ & $\begin{array}{c}\text { Dermatitis, } \\
\text { Neonatal rash, } \\
\text { Skin abscesses, }\end{array}$ & $\begin{array}{c}\text { Fungal infections } \\
\text { (especially chronic } \\
\text { mucocutaneous }\end{array}$ & $\begin{array}{c}\text { Growth failure, } \\
\text { Dysmorphic features, } \\
\text { Eczema, }\end{array}$ & $\begin{array}{l}\text { Upper \& lower } \\
\text { respiratory } \\
\text { infections, }\end{array}$ & Rare recurrent infections & $\begin{array}{c}\text { Early-onset } \\
\text { failure to thrive, } \\
\text { Neonatal }\end{array}$ & $\begin{array}{c}\text { Upper \& lower respiratory } \\
\text { infections, } \\
\text { Bronchiectasis, }\end{array}$ & $\begin{array}{c}\text { Upper \& lower respiratory } \\
\text { infections }\end{array}$ \\
\hline
\end{tabular}




\begin{tabular}{|c|c|c|c|c|c|c|c|c|c|}
\hline & $\begin{array}{c}\text { Respiratory infections, } \\
\text { Short stature }\end{array}$ & \begin{tabular}{|c|} 
Pneumonias, \\
Bronchiectasis, \\
Pneumatocele, \\
Fungal infections, \\
Bacterial \\
infections, Herpes \\
virus infections, \\
Dysmorphic \\
features, Vascular \\
abnormalities
\end{tabular} & \begin{tabular}{|c|} 
candidiasis,, \\
Severe viral \\
infections, \\
Bacterial infections, \\
Mycobacterial \\
infections, \\
Bronchiectasis, \\
Asthma, Eczema, \\
Dysphagia, \\
Failure to thrive
\end{tabular} & $\begin{array}{l}\text { Severe herpesvirus } \\
\text { infections, } \\
\text { Recurrent infections }\end{array}$ & $\begin{array}{c}\text { Pneumonia, } \\
\text { Bronchiectasis, } \\
\text { Chronic } \\
\text { rhinosinusitis, } \\
\text { Severe or } \\
\text { recurrent } \\
\text { herpesvirus } \\
\text { infections }\end{array}$ & & $\begin{array}{l}\text { erythema, } \\
\text { Eczema, } \\
\text { Psoriasiform } \\
\text { dermatitis, } \\
\text { Alopecia }\end{array}$ & $\begin{array}{l}\text { Viral infections, } \\
\text { Fungal infections, } \\
\text { Bacterial infections }\end{array}$ & \\
\hline Increased risk of malignancy & Yes & Yes & No & No & Yes & 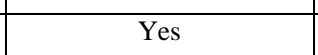 & No & Yes & Yes \\
\hline Laboratory parameters & $\begin{array}{c}\text { Hypogammaglobulinemia, } \\
\text { Reduced switched } \\
\text { memory B-cells } \\
\text { \& Tregs }\end{array}$ & \begin{tabular}{|c|} 
Elevated IgE, \\
Eosinophilia, \\
Decreased Th17 \\
cells, \\
B and T memory \\
lymphopenia
\end{tabular} & \begin{tabular}{|c|} 
Reduced switched \\
memory B cells, \\
Decreased Th17 cells, \\
Low IgG2 and IgG4, \\
\\
\end{tabular} & \begin{tabular}{|} 
Treg deficiency and \\
dysfunction, \\
Reduced $\mathrm{T}$ cells and $\mathrm{NK}$ \\
cells, \\
Hypergammaglobulinemia
\end{tabular} & \begin{tabular}{|c|} 
Decreased \\
IgA/IgG +/- \\
increased IgM, \\
Naive CD4 T-cell \\
$\&$ \\
Memory B-cell \\
lymphopenia with \\
elevated \\
transitional B- \\
cells
\end{tabular} & \begin{tabular}{|c|} 
Direct Coombs positive, \\
Hypergammaglobulinemia, \\
Elevated DNT cells, \\
Elevated plasma sFASL, \\
Elevated plasma IL-10, \\
Elevated plasma vitamin \\
B12 \\
\end{tabular} & \begin{tabular}{|c|} 
Elevated IgE, \\
Eosinophilia, \\
Anti-enterocyte \\
antibodies
\end{tabular} & \begin{tabular}{|c|}
$50 \%$ \\
Hypogammaglobulinemia, \\
Reduced Tregs, \\
Reduced switched memory \\
B-cells
\end{tabular} & Hypogammaglobulinemia \\
\hline
\end{tabular}




\begin{tabular}{|c|c|c|c|c|c|c|c|c|c|}
\hline References & $\begin{array}{c}\text { Milner, } \\
\text { Blood } 2015^{4}\end{array}$ & $\begin{array}{c}\text { Vogel, } \\
\text { J Clin Immunol } \\
2015^{3}\end{array}$ & $\begin{array}{c}\text { Forbes, } \\
\text { JACI } 2018^{7} ; \\
\text { Toubiana, } \\
2016^{32} \text { Blood } \\
2016^{32}\end{array}$ & $\begin{array}{c}\text { Hwa, } \\
\text { Growth Horm IGF Res } \\
2016^{31}\end{array}$ & $\begin{array}{c}\text { Coulter, } \\
\text { JACI } 2016^{28}\end{array}$ & $\begin{array}{c}\text { Neven, } \\
\text { Blood } 2011^{29}\end{array}$ & $\begin{array}{c}\text { Barzaghi, } \\
\text { JACI } 2018^{30}\end{array}$ & $\begin{array}{l}\text { Gamez-Diaz, } \\
\text { JACI } 2016^{27}\end{array}$ & $\begin{array}{c}\text { Schubert, } \\
\text { Nat Med } 2014^{26}\end{array}$ \\
\hline
\end{tabular}

Footnotes: ALPS: Autoimmune Lymphoproliferative Syndrome; LAD: lymphadenopathy; SM: splenomegaly; HM: hepatomegaly; AIHA: autoimmune hemolytic anemia; ITP: Immune thrombocytopenia; DNT: double-negative T-cells (CD3+TCR $\alpha \beta+C D 4 C D 8)$; LATAIE: LRBA deficiency with autoantibodies, Treg defects, autoimmune infiltration, and enteropathy; CHAI: CTLA-4 haploinsufficiency with autoimmune infiltration ; AD-HIES : autosomal-dominant hyper-immunoglobulin E syndrome, GOF : gain-of-function ; DN : dominant negative, AD : autosomal dominant, AR : autosomal recessive. 